\title{
Double gastric fluid level and aspiration pneumonitis in kerosene poisoning
}

\author{
Ryuki Esashi, ${ }^{1}$ Hirohisa Fujikawa ำ ${ }^{1,2}{ }^{2}$ Yu Kataoka, ${ }^{1}$ Minoru Saito ${ }^{1}$
}

'Department of Internal Medicine, Suwa Central Hospital, Chino, Nagano, Japan ${ }^{2}$ Department of Medical Education Studies, International Research Center for Medical Education, Graduate School of Medicine, The University of Tokyo, Bunkyo-ku, Tokyo, Japan

Correspondence to Dr Hirohisa Fujikawa; hirohisa.fujikawa@gmail.com

Accepted 5 February 2021

\section{DESCRIPTION}

An 85-year-old man with severe Alzheimer's dementia presented to the emergency department with dyspnoea and cough. The patient was discovered having a cup of clear liquid in a kerosene odour-filled room. He did not recollect what he had done. On physical examination, he had a respiratory rate and oxygen saturation of 30 breaths/min and 94\%, respectively, while breathing ambient air. Chest auscultation revealed bilateral coarse crackles, while no remarkable laboratory findings were found. Chest X-ray showed consolidation in bilateral lower lobes, and chest-abdomen-pelvis CT revealed double gastric fluid level (figure 1A) and consolidation in the right middle and left lower lobes (figure 1B). The patient, who was diagnosed with kerosene poisoning and aspiration pneumonitis, recovered following the intravenous administration of sulbactam-ampicillin.

Kerosene is produced from the fractional distillation of petroleum oil and is widely used as a fuel. ${ }^{1}$ The majority of cases of kerosene ingestion are unintentional poisoning in children, whereas it is for suicidal purposes among adults. To the best of our knowledge, this is the first case of accidental kerosene ingestion by an elderly patient with severe dementia.

Although kerosene ingestion may possibly lead to various complications including encephalopathy and arrhythmia, it mainly involves the respiratory system. ${ }^{2}$ Due to kerosene's low viscosity, a prompt diffusion occurs throughout the bronchial mucosa, causing severe lung inflammation after aspiration. ${ }^{2}$ Aspiration of hydrocarbons leads to two types of histopathological changes: a generalised hyperaemia and a focal bronchopneumonia. ${ }^{3}$ Because patients with respiratory symptoms soon after ingesting kerosene commonly progress fulminantly to respiratory failure, early recognition and intervention are critical. Chest imaging typically

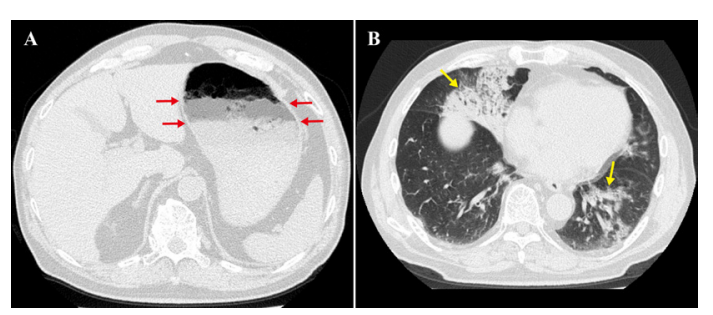

Figure 1 (A) Chest-abdomen-pelvis CT showing a double gastric fluid level (red arrows). (B) Chestabdomen-pelvis CT showing consolidation in the right middle and left lower lobes (yellow arrows).

\section{Learning points}

- Accidental ingestion of kerosene can lead to severe chemical pneumonitis and respiratory failure, requiring immediate intervention.

- The double gastric fluid level provides clues for diagnosis of kerosene ingestion, even if the physician is unable to obtain a history from the patient.

demonstrates bilateral interstitial infiltrates in the middle and lower lobes. ${ }^{4}$

Management of kerosene ingestion is mainly supportive care including oxygen inhalation and close monitoring of respiratory status. ${ }^{25}$ Although antibiotics are frequently prescribed, routine prophylactic antimicrobial use is not recommended for kerosene-induced pneumonitis. ${ }^{2}$ While one study showed that chemoprophylaxis appeared to decrease morbidity, ${ }^{6}$ another study revealed no evidence that recommended for use of antibiotics. ${ }^{7}$ Antibiotics are generally considered to be of use only if signs of secondary infection are present. ${ }^{2}$ Corticosteroids also should be avoided. ${ }^{27}$

Daffner et al reported double gastric fluid level in kerosene poisoning, ${ }^{8}$ which was identified on the chest plain radiography in 22 of 52 cases. The minimal amount of kerosene required to produce this sign was $5 \mathrm{~mL}$. Although the precise sensitivity and specificity are unknown, the sharpness of the kerosene-air interface is considered characteristic. ${ }^{8}$ To the best of our knowledge, this report is the first to describe the double gastric fluid level on CT in kerosene poisoning, showing that, although the patient did not remember the history of the present illness, the finding of double gastric fluid level with the typical chest imaging led to the diagnosis of kerosene ingestion.

As the number of elderly people with dementia is increasing worldwide, clinicians may encounter an increasing number of kerosene ingestion cases as well, similar to the present case. CT may provide clues for early diagnosis of kerosene ingestion.

Contributors RE acquired data and drafted the manuscript. HF, YK and MS reviewed and supervised the manuscript.

Funding The authors have not declared a specific grant for this research from any funding agency in the public, commercial or not-for-profit sectors.

Competing interests None declared.

Patient consent for publication Obtained. 
Images in...

Provenance and peer review Not commissioned; externally peer reviewed.

\section{ORCID iD}

Hirohisa Fujikawa http://orcid.org/0000-0002-8195-1267

\section{REFERENCES}

1 Lam NL, Smith KR, Gauthier A, et al. Kerosene: a review of household uses and their hazards in low- and middle-income countries. J Toxicol Environ Health B Crit Rev 2012;15:396-432.

2 Tormoehlen LM, Tekulve KJ, Nañagas KA. Hydrocarbon toxicity: a review. Clin Toxicol 2014;52:479-89
3 Scharf SM, Heimer D, Goldstein J. Pathologic and physiologic effects of aspiration of hydrocarbons in the rat. Am Rev Respir Dis 1981;124:625-9.

4 Gentina T, Tillie-Leblond I, Birolleau S, et al. Fire-eater's lung: seventeen cases and a review of the literature. Medicine 2001:80:291-7.

5 Shotar AM. Kerosene poisoning in childhood: a 6-year prospective study at the Princess Rahmat Teaching Hospital. Neuro Endocrinol Lett 2005;26:835-8.

6 Singh $\mathrm{H}$, Chugh JC, Shembesh AH, et al. Management of accidental kerosene ingestion. Ann Trop Paediatr 1992;12:105-9.

7 Steele RW, Conklin RH, Mark HM. Corticosteroids and antibiotics for the treatment of fulminant hydrocarbon aspiration. JAMA 1972;219:1434-7.

8 Daffner RH, Jimenez JP. The double gastric fluid level in kerosene poisoning. Radiology 1973;106:383-4

Copyright 2021 BMJ Publishing Group. All rights reserved. For permission to reuse any of this content visit

https://www.bmi.com/company/products-services/rights-and-licensing/permissions/

BMJ Case Report Fellows may re-use this article for personal use and teaching without any further permission.

Become a Fellow of BMJ Case Reports today and you can:

- Submit as many cases as you like

- Enjoy fast sympathetic peer review and rapid publication of accepted articles

- Access all the published articles

Re-use any of the published material for personal use and teaching without further permission

\section{Customer Service}

If you have any further queries about your subscription, please contact our customer services team on +44 (0) 2071111105 or via email at support@bmj.com.

Visit casereports.bmj.com for more articles like this and to become a Fellow 